\title{
A CASE REPORT OF RARE HEPATOSPLENIC T-CELL LYMPHOMA IN AN ADOLESCENT
}

\author{
Danijela Jovančić Petković1, Gordana Samardžija², Gordana Kostić1, Vesna Bogićević ${ }^{1}$
}

Hepatosplenic T-cell lymphoma is a rare neoplasm that commonly originates from a subset of T lymphocytes expressing $\gamma \delta T$-cell receptors. It is characteristic for young adult men. Clinical presentation usually includes massive enlargement of liver and spleen, typically without involvement of lymph nodes. Bone marrow is often affected in advanced stage of a disease. Clinical course can be progressive and in most cases prognosis is poor.

Although splenectomy is not obligatory diagnostic and therapeutic procedure in this case it was a way to establishing diagnosis, accompanied with immunophenotypization of bone marrow cells.

Combination of intensive chemotherapy and allogenic bone marrow transplantation lead to stabile remission.

Acta Medica Medianae 2021;60(3):67-71. receptor

Key words: hepatosplenic lymphoma, T-cell lymphoma, gamma/delta T-cell

${ }^{1}$ University Clinical Center Niš, Clinic of Pediatrics, Department of Hematology, Niš, Serbia

2Mother and Child Health Care Institute "Dr Vukan Čupić", Belgrade, Serbia

Contact: Danijela Jovančić Petković

48 Dr Zoran Djindjić Blvd., 18000 Niš, Serbia

E-mail: jovancic.danijela@yahoo.com

\section{Introduction}

Hepatosplenic T-cell lymphoma (HSTCL) is a rare subtype of Non Hodgkin lymphoma (NHL) that accounts from $2.3 \%$ to $3 \%$ of peripheral T-cell lymphomas in Europe and North America, respectively, with 5 years overall survival of $7 \%$ (1). Most of them originate from inactive T-cells expressing $\mathrm{\gamma} \delta \mathrm{T}$-cell receptors (TCR), although there are some cases associated with a $\mathrm{TCR}$. Malignant clone typically infiltrate the sinusoids of the liver and the spleen, showing the same pattern when found in the bone marrow (2). Median age of patients is 34 years, with a strong predominance of a male gender. The rarity of this disease, along with clinical presentation lacking nodal involvement and potentially imitating some infectious diseases or neoplasm of other origin, make HSTCL challenging for diagnosis and treatment (3).

\section{Case report}

A 17 years old boy was admitted to Children's Clinic Niš because of abdominal distension, fatigue and weight loose. Clinical examination indicated an enlarged liver palpable as a firm mass $6 \mathrm{~cm}$ below the right costal margin, and the spleen as a firm tender mass reaching the level under the umbilicus. There was no peripheral lymphadenopathy. High heart and respiratory rate were noted, but otherwise his clinical findings were normal.

Standard laboratory work up revealed high blood sedimentation rate ( 51 at first hour), mild thrombocytopenia $\left(95 \times 10^{9} / \mathrm{I}\right)$, as well as high level of beta2 microglobulin, while other standard biochemical, serological and immunological blood tests were within the reference ranges.

Enlargement of the liver and the spleen was confirmed by ultrasound and magnetic resonance imaging (Figure 1). Diameter of the liver was 260 $\mathrm{mm}$, without focal changes. The spleen was $340 \mathrm{~mm}$ long with marked areas of necrosis and hemorrhage. A small amount of a fluid was detected in the abdomen, but no enlargement of intra-abdominal lymph nodes. Chest X-ray finding was normal.

Bone marrow aspiration was conducted and revealed slightly hypocellular bone marrow with the presence of pathological blasts of L2 morphology less than $5 \%$.

Splenectomy was performed as a necessary diagnostic procedure as well as a part of treatment, concerning the presence of necrosis and hemorrhages in the spleen. The dimensions of the removed spleen were $35 \times 22 \times 13 \mathrm{~cm}$ and its weight was 
almost $5 \mathrm{~kg}$. Histopathological examination demonstrated infiltration of a red pulp by intermediate lymphoid cells with a moderate amount of cytoplasm, placed mostly in the sinusoids. Immunohistochemical assessment revealed positivity of these cells for $\mathrm{CD} 3$ and CD56, while they were negative for CD4, CD8, CD5, CD20, CD79a, CD30, CD10, ALK1,
TdT. Typical pattern of infiltration with characteristic clinical occurrence suggested the diagnosis of HSTCL (Figure 2). Additional PCR (polymerase chain reaction) analyses on DNA from spleen tissue specimen showed monoclonality of lymphoid cells concerning $Y$ chain of TCR.

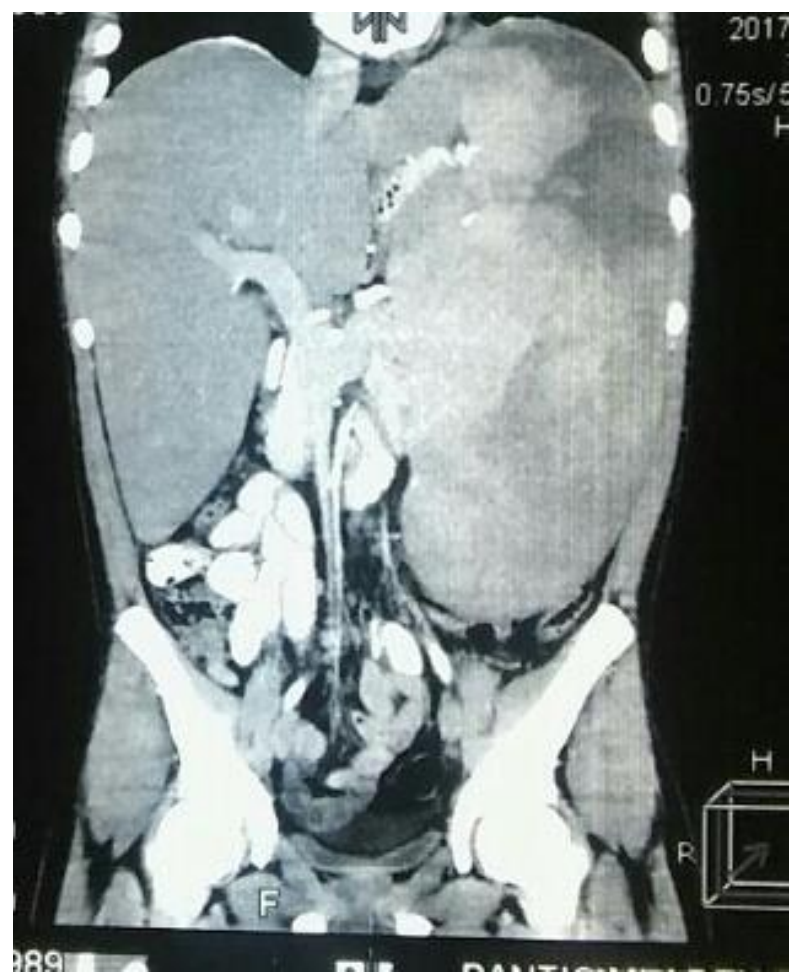

Figure 1. Enlarged liver and spleen found on magnetic resonance imaging

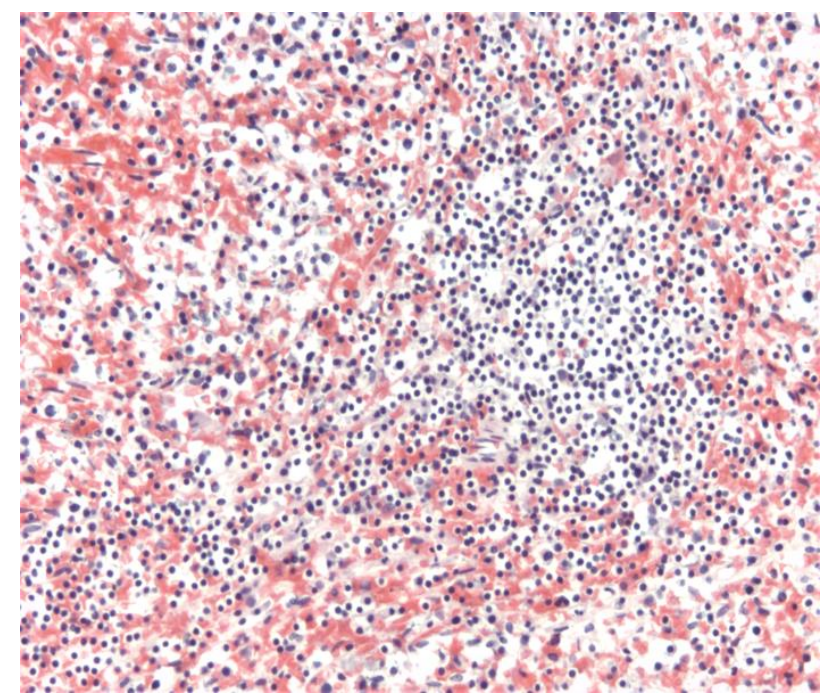

Figure 2. Spleen involvement with sheets of neoplastic lymphoid cells involving sinuses of the spleen (hematoxylin and eosin [H\&E] stain; original magnification $\times 400$ ) 
Examination of the the bone marrow was repeated a week after the first one and this time the infiltration with pathological lymphoid cells was $40 \%$. Flow cytometry was performed and findings of immunophenotypic analysis confirmed $\mathrm{T}$ cell origin of pathological cells with high expression of iCD3, sCD3, CD7, CD2, CD5, TCRyठ/sCD3 (Figure 3). Conventional chromosomal analysis on bone marrow aspirate specimen showed normal male karyotype.
Treatment was implemented according to Hyper CVAD chemotherapy protocol including corticosteroids, vincristine, methotrexate, doxorubicin, cyclofosfamide and high doses of cytarabine, followed by allogenic bone marrow transplantation from HLA identical non related donor.

Patient is in a complete remission after three years of a follow up.
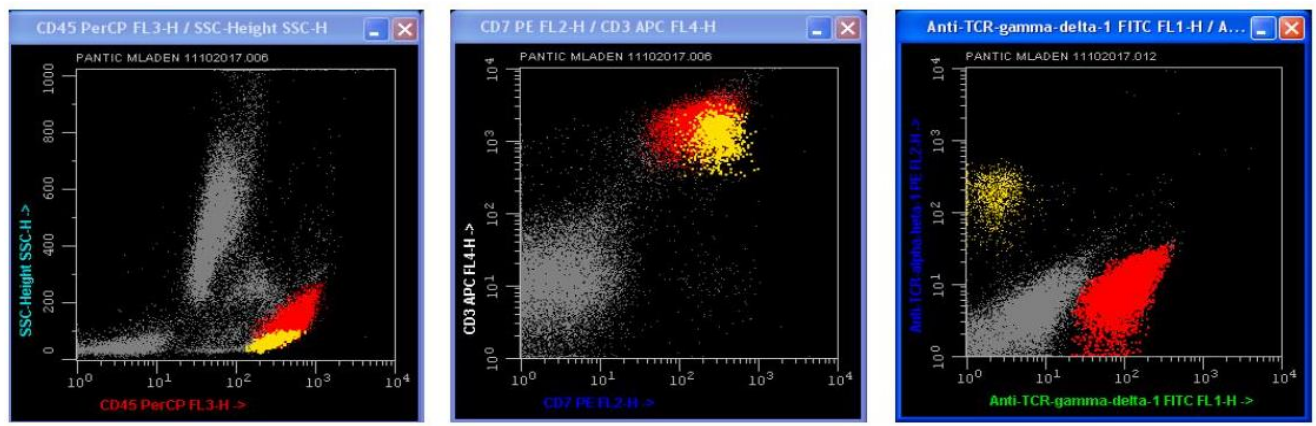

Figure 3. Flow cytometry immunophenotypic histograms of bone marrow aspirate show that pathological cells (red) are positive for CD3, CD7 and TCRYठ

(FITC, fluorescein isothiocyanate; PE, phycoerythrin, APC, allophycocyanin, PerCP, peridinin chlorophyll protein)

\section{Discussion}

HSTCL is a rare lymphoid neoplasm found mostly in young adult men. Among pediatric patients Burkitt lymphoma, diffuse large B-cell lymphoma, T cell lymphoblastic lymphoma and anaplastic large cell lymphoma are almost exclusively seen types of $\mathrm{NHL}$, while other forms are sporadic (4).

In a significant number of patients diagnosed with HSTCL there is a history of immunosuppression or autoimmune disorders, especially inflammatory bowel disease (5).

Abdominal distension due to the enlargement of the liver and spleen is typical clinical presentation, accompanied with the absence of lymphadenopathy, which makes this entity intriguing for diagnosis. Cytopenias in the peripheral blood can be seen mostly as a result of hypersplenism, but also because of bone marrow infiltration and leukemic evolution in advanced cases. The bone marrow is involved in approximately two-thirds of the patients at the moment of diagnosis (6). At this point, there could be a diagnostic dilemma whether it is an acute leukemia with extramedullar deposits or lymphoma spreading to the bone marrow. Nevertheless, lymphocytosis and leukemic clinical presentation are rare, occurring in $1-2 \%$ of patients (6).

Our patient was diagnosed with the typical organ involvement and mild thrombocytopenia. A prognostic correlation between outcome and degree of thrombocytopenia has been noted (7). Subsequent assessments of bone marrow specimens demonstrated propagation of malignant cells.
Positivity of the blasts from bone marrow for y TCR in combination with typical sinusoid infiltration of the spleen and clinical manifestations was decisive fact for diagnosis.

Splenectomy is rarely indicated in spite of the fact that spleen can be grossly enlarged (from 550 $\mathrm{gr}$ to $6500 \mathrm{gr}$ ). It was the way thru the diagnosis in the past, but lately liver and/or bone marrow biopsy are the common diagnostic procedures (3).

Inside the spleen there is an expansion of the red pulp and sinusoidal infiltration composed of small to intermediate cells with a moderate amount of cytoplasm and no granules. Bone marrow biopsy specimen also demonstrates sinusoidal as well as interstitial infiltration, but in the liver a three patterns of infiltration can be found: sinusoidal, periportal with affecting sinusoids and nodular parenchymal type (2).

Among genetic anomalies described in malignant clones of HSTCL the most important are isochromosome $7 \mathrm{q}[\mathrm{i}(7 \mathrm{q})]$ and trisomy 8 , while other, less common alterations include ring chromosome 7, loss of $Y$ chromosome or deletion of chromosome 10. McKinney and coworkers noted that the majority of gene alterations resulted in loss of function of tumor-suppressor genes (8). Also, activation of the JAK/STAT signaling pathway is commonly observed in HSTCL resulting from activating mutations of the genes in this pathway (9).

Considering a rarity of $\mathrm{HSTCL}$, it is difficult to draw conclusions about the effectiveness of different treatment modalities. Use of standard CHOP and $\mathrm{CHOP}-$ like regimens gives poor results with median 
survival time of only 16 months and progression that mostly involves initial site of disease (10). Intensive chemotherapy protocols, containing high dose cytarabine, and followed by bone marrow transplant suggest a better overall survival (11). Also, splenectomy could be beneficial in some cases.

\section{Conclusion}

HSCTL is a rare aggressive malignant disease presenting with progressive clinical course. There- fore, it has to be considered in young male patients with hepatosplenomegaly, especially if there is a history of immunodeficiency or autoimmunity. Splenectomy could be a useful diagnostic and therapeutic tool. Intensive chemotherapy along with bone marrow transplantation could improve prognosis.
1. Vose J, Armitage J, Weisenburger D. International peripheral T-cell and natural killer/T-cell lymphoma study: pathology findings and clinical outcomes. J Clin Oncol 2008;26(25):4124-30. [CrossRef] [PubMed]

2. Yabe M, Miranda RN, Medeiros L. Hepatosplenic T-cell lymphoma: a review of clinicopathologic features, pathogenesis, and prognostic factors. Hum Pathol 2018;74:5-16. [CrossRef] [PubMed]

3. Pro B, Allen P, Behdad A. Hepatosplenic T-cell lymphoma: a rare but challenging entity. Blood 2020; 136(18):2018-26. [CrossRef] [PubMed]

4. Link MP, Weinstein HJ. Malignant Non Hodgkin lymphoma in children. In: Pizzo PA, Poplack DG. (eds) Principles and practice of pediatric oncology. Philadelphia: Lippincot Wiliams\&Wilkins, 2006:722-50.

5. Yabe M, Medeirod L, Daneshbod Y, Davanlou M, Bueso-Ramos CE, Moran EJ, et al. Hepatosplenic T-cell lymphoma arising in patients with immunodysregulatory disorders: a study of 7 patients who did not receive tumor necrosis factor-a inhibitor therapy and literature review. Ann Diagn Pathol 2017;26:16-22. [CrossRef] [PubMed]

6. Vega F, Medeiros L, Bueso-Ramos C, Jones D, Lai R, Luthra $R$, et al. Hepatosplenic gamma/delta lym- phoma in bone marrow. A sinusoidal neoplasm with blastic cytologic features. Am J Clin Patol 2001; 116(3):410-19. [CrossRef] [PubMed]

7. Ferreri AJ, Govi S, Pileri S. Hepatosplenic gammadelta T-cell lymphoma. Crit Rev Oncol Hematol 2012; 83(2):283-92. [CrossRef] [PubMed]

8. McKinney M, Moffitt AB, Gaulard P, Travert M, De Leval $L$, Nicolae $A$, et al. The genetic basis of hepatosplenic T-cell lymphoma. Cancer Discov 2017;7(4): 369-79. [CrossRef] [PubMed]

9. Van Arnam JS, Lim MS, Elenitoba-Johnson KSJ. Novel insight into the pathogenesis of T-cell lymphomas. Blood 2018;131(21):2320-30. [CrossRef] [PubMed]

10. Falchook GS, Vega $F$, Dang $N H$, Samaniego $F$, Rodrigues MA, Champlin RE, et al. Hepatosplenic gamma-delta T-cell lymphoma: clinicopathological features and treatment. Ann Oncol 2009;20(6):108085. [CrossRef] [PubMed]

11. Rashidi A, Cashen AF. Outcomes of allogenic stem cell transplantation in hepatosplenic T-cell lymphoma. Blood Cancer ] 2015;5(6):e318. [CrossRef] [PubMed] 


\title{
PRIKAZ SLUČAJA RETKOG HEPATOSPLENIČNOG T-ĆELIJSKOG LIMFOMA KOD ADOLESCENTA
}

\author{
Danijela Jovančić Petković1, Gordana Samardžija², Gordana Kostić1, Vesna Bogićević1
}

\author{
${ }^{1}$ Univerzitetski klinički centar Niš, Klinika za pedijatriju, Odeljenje hematologije, Niš, Srbija \\ 2Institut za zdravstvenu zaštitu majke i deteta "Dr Vukan Čupić", Beograd, Srbija \\ Kontakt: Danijela Jovančić Petković \\ Bulevar dr Zorana Đinđića 48, 18000 Niš, Srbija \\ E-mail: jovancic.danijela@yahoo.com
}

Hepatosplenični T-ćelijski limfom je retka forma limfoma, koja uglavnom potiče od grupe limfocita, koji eksprimiraju $ү \delta$ T-ćelijski receptor. Karakteristično se javlja kod mlađih odraslih osoba muškog pola. Klinička prezentacija najčešće uključuje masivno uvećanje jetre i slezine, bez zahvatanja limfnih nodusa. Koštana srž često je zahvaćena kod uznapredovalih formi bolesti. Klinički tok je progresivan i, u većini slučajeva, bolest ima lošu prognozu.

Iako splenektomija nije obavezna dijagnostička i terapijska procedura, u ovom slučaju vodila je postavljanju dijagnoze zajedno sa imunofenotipizacijom ćelija kostne srži. Kombinacija intenzivne hemioterapije i alogene transplantacije koštane srži uvela je bolesnika u stabilnu i dugotrajnu remisiju.

Acta Medica Medianae 2021;60(3):67-71. receptor

Ključne reči: hepatosplenični limfom, T-ćelijski limfom, gama/delta T-ćelijski 